\author{
STUDIA IURIDICA TORUNIENSIA \\ PRZISMIANY POLSKIEGO PRAWA, TOM DRUGJ \\ pod red. Ewy Kustry, Toruń 2002
}

Matgorzala Anna Nesterowicz

\title{
Pomoc publiczna dla żeglugi morskiej i budownictwa okrętowego we Wspólnocie Europejskiej i Polsce
}

Na podstawie Układu Europejskiego zawartego 13 grudnia 1993 r. pomiędzy Polską i Wspólnotami Europejskimi oraz ich paístwami czlonkowskimi ${ }^{1}$, zasady prawa konkurencji w formic podobnej do zasad obowiazujących w prawie europejskim mają zastosowanic do relacji handlowych pomiędzy Polską i Unią. Zgodnie z art. 63 Układu za niezgodne z właściwą jego realizacją uznaje się:

1) zawieranie między przedsiębiorstwami wszelkich porozumień lub praktyk, których rezultatem jest ograniczanie lub znieksztalcanie konkurencji,

2) nadużywanie przez jedno lub więcej przedsiębiorstw dominującej pozycji na terytoriach Polski lub Wspólnoty jako calości, lub na ich znacznej części,

3) udzielanie pomocy publicznej, która znicksztatca lub grozi znieksztalceniem konkurencji, przez faworyzowanie niektórych przedsiębiorstw lub produkcji niektórych towarów, jeżeli może ona micé negatywny wpływ na handel między Polską a Wspólnotami.

W zakresie prawa konkurencji dolyczącego przedsiębiorstw, Polska dość szybko przystąpiła do hamonizacji tej dziedziny z prawem europcjskim. Jeszcze przed podpisanien Układu, gdyż juz w $1990 \mathrm{r}$., ogłoszona została ustawa o przeciwdziałaniu praktykom monopolistycznym i ochronie interesów konsumentów ${ }^{2}$, której zasady były zbliżone do zasad przewidzia-

1 Dec. 93/743/Euratom, JCSC, LiC, OJ 1993, L 348.

2 Dz.U. z 1990 s. Ni 14, poz. 88. Por, S. Gronowski, Ustawa antymonopolowa -.. komentarz, Warszawa 1996. 
nych w art. 81 i 82 traktatu rzymskiego (uprzednio art. 85 i $86^{3}$ ) oraz w rozporządzeniu 4064/89 o koncentracji przedsiębiorstw". Ustawę tą naz stępnie kilkakroinie nowelizowano". Ostatecznie zastapila ja nowa ustawa o ochronie konkurencji i konsumentó $w^{6}$ z 2000 r. Jej unomowania dostó sowaly calkowicie plawo polskie do zasad Wspólnoty Europejskiej w te driedzinie. W 1990 !. powotano równieź. Urząd Antymonopolowy, którego zadaniem jest realizacja zadań z zakresu przeciwdziatania praktykom mo nopolistycznym, rozwoju konkurencji i ochrony interesu konsumentów W 1996 : przemianowano go na Urząd Ochrony Konkurencji i Konsumentós

Jeżeli chodzi natomiast o pomoc publiczna której dotyczy art. 63 (3) Układu i której poświęcony jest niniejszy artykul, to przez okres pierw szych pięciu lat od zawarcia Układu praktyka jej udzielania była oceniane stosunkowo tagodnie przez Wspólnotę ze względu na słabszy rozwój go spodarczy Polski w porównaniu do krajów WE. W tym czasie Polska byla jednakze zobowiązana poczynić kroki $w^{\prime}$ celu harmonizacji zasad rządzą cych pomoca publiczna w Polsce z zasadami traktatu rzymskiego oraz za pewnic przejrzysty system informacji o pomocy publicznej?. Okres kolej nych pięciu lat mial być poświęcony dalszej harmonizacji. W 2000 r. nchwa lono w Polsce ustawę o warunkach dopuszczalności i nadzorowaniu pomocy publicznej dla przedsiębiorców ${ }^{8}$ oraz szereg rozporządzeń dolyczących pomocy scktorowej, w tym rozporządzenia RMI w sprawie udzielania pomocy publicznej w sektorze zeglugi morskiej" oraz w sprawie udzielania pomocy publicznej w sektorze budownictwa okrętowego ${ }^{10}$.

Postanowienia dotyczące pomocy państwowej we Wspónotach Europejskich zawarto w art. 87-89 (uprzednio art. 22-94) traktatu rzymskiego." Zgodnie z art. 87.1 ,pomoc przyznawana przez państwa lub przy uzyciu zasobów państwowych, w jakiejkolwiek formie", jezeli pr\%ez uprzywilejowanie określonych przedsiębiorstw lub galęzi produkcji zakłóca lub zagraża zakłóceniem konkurencji i jeżeli wpływa na handel pomiędzy państwami czlonkowskimi, będzie uznana za niezgodną z zasadami wspólnego rynku.

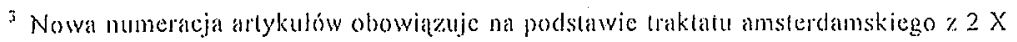
1997, klóly wszedl w zycie 1 V 1999.

"OJ 1990, 1, 257, 21 IX 1990.

s Tekst jednolity ogloszonow 1999 r., Dz.U. * 1999 r. Nr 52, poz. 547. Por. Ch. Tarding and M. Kepinski, The Polish Law Against Monopolistic Practices, Europcan Compelition 1, aw Review 2001, s. 181-188.

${ }^{6}$ Dz.U. z 2000 r. Ni 122, poz. 1318.

${ }^{7}$ U. Plowiec, Slosunki Polski z Uniq Europejska na podstawie Uklad Europejskiego, [w:] Polsta i Unia Europejska: stan obecny i wyzwania na przyszlośc, Warszawa 2000 , s. 60.

${ }^{3}$ Dz. (J. \& 2000 i: Ni 60, poz. 704.

"D\%.U. ะ 2001 r. Nr 28, poz. 309.

${ }^{10}$ D\%.U. $\% 2001$ r. Ni 28, po\%. 304. 
Zaklócenie konkurencji lub zagrozenie jej zakłóceniem jest warunkiem sine qua non dla uznania pomocy państwowej za niezgodną ze wspólnym rynkiem". Artykuł 87.2 określa rodzaje pomocy, które wyjątkowo uznane sa 7á zgodne ze wspólnym rynkicm, mimo ze wedhug art. 87.1 powinny być aznane za niezgodne. Do tej kategorii naleza: „pomoc o charakte socjalnym na rzecz indywidualnych konsumentów, jezeli jest ona un celu likw dyskryminacji ze względu na pochodzenie towarów" "i "lub inne nadzwydacji szkód wyrzadzonych przez katastrofy przyrodnicze hub in czajne zdarzenie".

Za zgodne z zasadami wspólnego rynku moga takze zostać uznane:

a) pomoc w celu wspierania rozwoju gospodarczego regionów, w których poziom zycia jest nienormalnie niski lub regionów szczególnie dotkniętych berrobociem,

b) pomoc w celu wspiennia realizacji ważnych projektów $w$ interesic ogólnoeuropejskim lub w celu zapobiezenia szczególnym zaburzeniom gospodarki któregokolwiek z panstw czitonkowskich,

c) pomoc w celu rozwoju pewnych dziedzin gospodarki lub nicktórych regionów gospodarczych, o ile nie zmienia warunków wymiany handlowcj w sposób spizeczny ze wspólnym interesem,

d) pomoc przeznaczona na wspieranie kultury i ochronę dziedzictwá kulturowego z zastrzezeniem, ze pomoc taka nie zmieni wam món handlu i konkurencji we Wspólnocie w sposób sprzeczny ze wáne decyza Rady, stanowiącej wiek-

e) inne kategorie pomocy określone Kocy Komisji (art. 87.3) ${ }^{12}$.

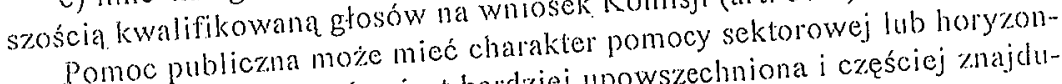
Pomoc publiczna moze mied chan bardziej upowszechniona i cześsciej znajdutalnej. Pomoc Komisji Buropejskiej. Jest ona udzielana, zgodnie \% potrebami regionu, wszystkim przedsiębiorstwom na określonym terytorium w celu, np. wsparcia programów badań i rozwoju, wspomozenia aktywności matych i średnich przedsiębiorstw (SME), ochroné środowiska, przekwalifikowanie pracowników etc. Pomoc sektorowa natomiast jest udziclana przedsiębiorstwom w sektorach wrażliwych (np. odzieżowym, tekstylnym, motoryzacyjnym, stoczniowym, stalowym i górniczym) w celu restrukturyzacji określonego działu gospodarki. Nie moze być stosowana dla utrzymywania upadających przedsiębiorstw. Ma zazwyczaj charakter drugofalowy, a dotacje są degresywne ${ }^{13}$.

1 Decyzja Komisji 98/95, Italian Republic (C-15/98) and Sardegna lines - . Scr.

Marittimi della Sardegna $\mathrm{SpA}(\mathrm{C}-105 / 99)$ v. Conisk prawa wspólnotowego, foruń 1998 ,

S. $329-331$.

13 U. Plowiec, op.cit., s. 60).61 
Pomoc państwowa może przybrać forme dotacji pienięznych i rzeczowych, czyli bezpośrednich wydatków z budżetu państwa, wiadz regionalnych lub lokalnych, preferencji kredytowych (kredytów obciązonych stopa oprocentowania niższą od rynkowcj udziclonych przez. bank, któremu państwo refunduje różnice lub sama agencję państwowa), gwarancji lub poręczenia kredytów przez budżet lub fundusze finansowane z budzetu, preferencji podatkowych (zwolnień lub ulg podatkowych, redukcji stopy podatku, odroczenie terminu płatności etc.), instrumentów kapitatowych (np. zakupu akcji firmy przez fundusze państwowe przy ustalenie dywidendy poniżej poziomu rynkowego), obniżenia ależności ná cele socjalne, zanıówień państwowych realizowanych po cenie wyzszej niż rynkowa lub na korzystniejszych warunkach etc. in

Komisja ma uprawnienia kontrolne w stosunku do istnicjacych i wprowadzanych programów ponocy. W pierwszym przypadku Komisja bada systemy pomocy publicznej istnicjące w państwach czlonkowskich. Jeżeli stwierdzi, po uprzednim wezwaniu zainteresowanych do przedstawienia uwag, że pomoc jest niezgodna ze wspólnym rynkiem lub jest nadużyana, zadecyduje o zniesieniu lub zmianie pomocy prze odpowiednie państivo czlonkowskie w określonym przez Konisje terminie (art. 88.1,2). W wyjatkowych przypadkach Rada może uznać taka pomoc za zgodną ze wspólnyın ryıkiem, jeżeli okoliczności uzasadnają taką decyzję. W drugim plzypadku, Komisja jest informowana przez panstwa o projektach pomocy publicznej (art. 88.3). Jeżeli uzna, że planowana pomoc będzie niezgodna ze wspólnym rynkiem, powiadomi o tym panstwo i zażąa zanicchania projektu lub wprowadzenia do niego zmian. W obu przypadkach, jezcli pánstwo odmawia wykonania decyzji Komisji, moze ona skierować sprawę na droge sądową bezpośrednio do Trybunatu Sprawiedliwości (art. 88.2).

Sektorem gospodarki wspieranym wielokrotnie $z$ funduszy panstwowych jest żegluga morska. Jej zapotrzebowanie na pomoc publiczna wciąz wrarasta. W latach sicdemdziesiątych flota podnosząca bandery państw członkowskich WE była światowa potęgą. Krótko potem rozpoczęły się jednakze procesy niekorzystne dla WE.W latach 1970-1995 liczba statków plywających pod banderami państw członkowskich zmalała z $32 \%$ do $14 \%$ światowego tonażu, podezas gdy liczba statków plywających pod tzw. dogodnymi banderami wzrosta z $19 \%$ do $38 \%{ }^{15}$. Obecnie okoto $50 \%$ tonazu kontrolowanego przez przedsiębiorców wspólnotowych jest zarejestrowane w tzw. otwartych rejestrach, a nie w krajach rzeczywistej siedziby fïrn właścicieli ${ }^{16}$.

14 Por. A. Pornalczyk, Rodzaje, formy i instrumenty pomocy publicznej w Unii Europejskiej i w Polsce, [w:] Pomoc publiczna dla przedsiębiorsiw w Unii Europejskiej i w Polsce, Warszawa 1998, s. 19-20.

is M. Clough and $\mathrm{P}$, Randolph, Shipping and SC competition Law, London 1991, s. 60.

16 V. Powes, EC Shipping liaw, Loncion 1998, s. 181. 
Polska, będąca niegdyś liczącym się panstwem morskim, obecnie nie posiada wielu statków. Co więcej, ich liczba z każdym rokien maleje. Dnia 31 grudnia $2000 \mathrm{r}$. można było jedynie doliczyć sie 128 statków kontrolowanych przez kapitat polski, z których jedynie 41 podnosiło banderę polska, w stosunku do 149 statków kontrolowanych przez polski kapital i 61 pod banderą polską rok woześniej. Zmniejsza się również tonaż floty polskiej. W 1999 i. kapital polski kontrolował 2959736 DWT, w tym 1692737 DWT pod banderá polską. Rok później, w $2000 \mathrm{~s}$. tonaż ten wynosit jedynie 2551318 DWT, w tym 1072465 DW' pod bandera polską. W ciagu jednego roku bandera polska utraciła ponad 600000 DWT, a więc ponad 1/3. W skład polskiej floty wchodza głównie statki towarowe, przeważnic masowce. Prawie $40 \%$ floty ma pomiędzy 21 a 25 lat, a $20 \%$ pomiędzy 11 a 15 lat. Statków nowych, poniżej 10 lat, jest niewiele ponad $10 \%$. Tonażowo, slatki w wieku 21-25 lat stanowia okoto $25 \%$ floty, podobnie stakki w wieku 6-10 lat. Statki nowe stanowia okoto $15 \%$. Prawie 70\% statków kontrolowanych przez polski kapitał podnosi banderę cypryjską, Wysp Marshalla, maltańską, Wysp Bahama, panamską lub liberyjską. Liczba statków zarejestrowanych jedynie na Cyprze i Wyspach Marshalla przewyższa liczbę statków zarejestrowanych w Polsce, a tonaż takich statków zarejestrowanych na Cyprze, Malcie i w Panamie przewyzszá caly tonaż statków podnoszących banderę polską ${ }^{17}$.

Dogodne bandery wiążą się dla armatora z oszczędnościami: podatkowymi, na koszlach zalogowych (brak ograniczen dotyczących kraju pochodzenia marynarzy zatrudnianych na statku) oraz kosztach zwiąanych z wymaganiami w zakresie bezpieczeństwa morskiego (jeżeli państwo bandery nie jest stroną określonych konwencji dotyczących bezpieczeństwa morskiego lub ochrony środowiska). Różne środki zostaly przedsięwziçte przez państwa czlonkowskie Wspólnoty, aby zapobiec utracie statków i uczynić swoje rejestry bardziej atrakcyjnymi, w szczególności tworzenie tzw. „drugich rejestrów" i udzielanie pomocy państwowej statkon plywającym pod ich banderami.

"Drugie rejestry", inaczej zwane specjalnymi, mają na celu zapewnicnie armatorom krajowym dogodnych warunków, w szczególności obniżenie kosztów eksploatacyjnych (np. poprzez przyznanie ulg podatkowych i prawa zatrudniania obcokrajowców nie-obywateli WE jako marynarzy), dla wzmocnienia ich pozycji na międzynarodowym rynku żeglugowym, bez konieczności zmiany przynależności. Rejestry takie wprowadzity m.in. Dania, Finlandia, Hiszpania, Niemcy, Norwegia i Wielka Brytania ${ }^{18}$. Z planem ustanowienia europejskiego rejestru statków Euros nosiła się równiez Ko-

17 Informacja z Ministerstwa Transportu i Gospodarki Morskiej, 3 IX 2001.

18 I. Lopuski w: Prawo Morskie, 1. 1, Bydgoszcz 1996, s. 185. 
misja Buropejska, z pomysłu jednak ostatecznie zrezygnowano w $1996{ }^{10}$ $W$ Polsce "drugi rejestr" równiez nie zostat przyjety.

Pomoc państwowa jest metodą na zapewnienie przedsiębiorstwom zeglugowym, posiadającym lub eksploatujacym statki podnoszące rodzima banderę, konkurencyjnej pozycji na rynku oraz pióba zalrzymania stakków w rodzimych rejestrach. Państwa czlonkowskie WE udzielaja takiej pomocy w ramach tzw. pomocy sektorowej, w celu, rozwoju pewnych dziectzin gospodarki" (art. 87.2 (c)). Jest to środek nawet popularniejszy od „drugich rejestrów", gdyź pomocy publicznej udziela kazde panstwo. Niektóre państwa nie wprowadzity natomiast dodatkowego rejestu statków. Polska równiez pozostata jedynie przy rejestrze podstawowym, tak więc pomoc jest jedynym środkiem, jaki nasze państwo może zapewnić dla poprawy konkurencyjności polskiej floty.

W 1989 r. Komisja uchwaliła wytyczne (cridelines) $)^{20}$ o warunkach zgodności z zasadami wspólnego rynku pomocy panstwowej w transporcie morskim. Pomoc taka musiata być udzielona w proporcji do celü, być przejraysta, czasowa i malejąca oraz nie zwiększać potencjału sektom o wyraznie nadmiencj zdolności wytwórczej. Pomoc mogla mieć formę m.in. dotacji inwestycyjnych, ulg podatkowych, wsparcia szkolen marynarzy i dotacji do składek na ich ubezpieczenia spoleczne. Nie mogla przekraczać określonego pulapu obliczonego na podstawie różnicy kosztów operacyjnych określonego statku plywającego pod bandera państwa czlonkowskiego i kosztów operacyjnych hipotetycznego statku plywającego pod dogodiną banderaz (np. Cypru). W $1992 \mathrm{r}$. wynikla potrzeba rewizji wytycznych. Uważano, ze pułap pomocy panstwowej nie powinien być obliczany na podstawie hipotetycznej róznicy kosztów operacyjnych statków, ale raczej na podstawie rozmiarów i tonażu danego statku, przynoszonych przez niego zysków i struktury zatrudnienia. Wysokość pomocy powinna być ponadto bardziej związana z określonymi celami, jakim dana pomoc ma stuzyć.

Nowe wytyczne dotyczace pomocy panstwowej w transporcie morskim zostaty uchwalone w $1997 \mathrm{r}$ " Maja one zastosowanie do zeglugi morskiej, ale nie do budownictwa statków, gdyz tego dotyczy odrębny akt prawny ${ }^{22}$. Stanowia one odejście od poprzedniej polityki dość oszczędnego udzielania pomocy państwowej zegludze. Przyznaje się, ze dotychczasowa polityka oparta na zasadach swobodnego dostepu do rynku ladunkowego i wolnej

19 1. Kujawa, W'spólna polibka żeglugowa Unii Europejskiej, Gdańsk 1999, s. 103-106; V. Power, op.cil., s. $187 \mathrm{in}$.

303 VIII 1989, SEC (89)921 final.

21. Wytyczne Komisji definiujące warunki udzielania pomocy publiczncj dla zeglugi zgodnej ze wspólnym rynkiem, o. 1997, C 205/7

22 Dyrektywa Rady Furopy 90/684/31:C o pomocy panstwowej dla promystu stoczniowego, OJ 1990, L 380/12, zmieniona przcz Dyrektywe 94/73/LC, OJ 1994, L 351/12. 
konkurencji, a pozbawiona wsparcia państwa - okazala się nieskuteczna dla rozwoju floty WE. Zgodnie z now'ymi wytycznymi, transport morski uznano za specjalna, wymagająca odrębnego traktowania, galaź gospodarki. Pomoca pańslwowa jest ,kazda korzyść finansowa udzielona w jakicjkolwiek formie przcz organ pańsiwowy" (gwarancje, pozyczki, subwencje, wytączenia podatkowe, emisja obligac.ji pr\%ez państwo etc.). Moze ona zostać udzielona statkom zarejestrowanym w rejestrze danego państwa czlonkowskiego i podnoszacym banderę tego panstwa. Celem pomocy powinien być wrzost konkurencyjności floly, ochrona interesów pracowników pochod\%acych ze Wspólnoty (na statkach i na ląlzie), ochrona know how we Wspólnocie i rozwój umiejętności oraz poprawa warunków bezpieczeństwa i ochrony środowiska. Pomoc panstwowa nie moze zostać udzielona kos\%tem innego państwa i zakłócać konkurencji pomiędzy państwami czlonkowskimi w sposób niezgodny z zasadami wspólnego rynku. Informacje o pomocy powinny być dostępne dla wszystkich zainteresowanych (zgodnie z. zasadą przejrzystości). Może być ona ndzielona w formie: zmniejszenia lub zniesienia obciazzen fiskalnych i socjalnych, wsparcia w wymianie zatóg unijnych na statkach w odlegtych od UE portach, inwestycji tonazowych, inwestycji w infrastrukture ladowa zwiazana z transportem morskim w regionach stabiej rozwiniętych, szoolén i podnoszenia kwalifikacji malynarzy, udziatu w programach restukturyzacji i prywatyzacji przedsiębiorstw zeglugowych oraz pomocy zwiazanej z realizacja kontrak tów o świadezenie uslug użyteczności publicznej ${ }^{23}$. Dopuszczalnym pulapem pomocy dla zeglugi jest calkowita redukcja podatkow i swiadezeń socjalnych marynary, a takze podatku dochodowego z dziatalności zeglugowej (altenatywnie wysokość bezpośrednich subwencji nie moze plzekroczyć wysokości tych ulg), tak więc danemu przedsiębiorstwu można pozostawić catośc wypracowanych przez niego środków $w^{24}$. W rezultacie, państwa czlonkowskic stosuja róznego rodzaju metody dla poprawienia konkurencyjności floty, m.in.: worzenie korzystnych warunków podatkowych dla statków ratejestrowanych w rejestrze krajowym (np. wieloletnie ulgi podatkowe da ' $\%$ ysku osiagniętego ze sprzedaży statku, jezeli zostat ponownie zainwestowany $w$ transport morski, wprowadzenie statego podatku opartego na lonazu statku, a nie na osiagniętych zyskach elc.), stosowanie środków, mających na celu poprawe struktury zatrudnienia (np. obnizone stawki ube\%pieczenia spotecznego lub obnizony podatek dochodowy dla obywateli Wspólnoty zatrudnionych na statkach zarejestrowanych w państwach czlonkowskich). Niektóre państwa czlonkowskie przyznają armatorom $1 \% w$.

23 Por. J. Kujawa, op.cit., s. 112.

2:1 Por. K. Dąlorowski, Uregulowania Wspólnoty Europejskiej w Wansyoscie morskim a polska polityka ל̇eglugowa (aspekty ekonomiczne), Studia Europejskic 1998, 1(5), s. 124. 
pomoc inwestycyjną w celu, np. zakupu uzywanych i nowych statków lub modernizacje posiadanej floty. Tego rodzaju pomoc, ze względu na swój charakter, dość często może skutkować zaklóceniami wolnej konkurencji, tak więc Komisja analizuje kazdy przypadek bardzo dokladnie zanim wyda decyzje. lnne rodzaje pomocy inwestycyjnej sa raczej akceptowane, np. w celu unowocześnienia uządzeń na statku, podwyższenia standardów bezpicczeństwa na statku do przewyzszających minimalne standardy wymagane prze\% międzynarodowe konwencje ele. Subwencje udziclone armatorom na budowę lub modernizacje statku muszą być jednocześnie zgodne z niżej przedstawionymi regulacjami o pomocy dla budownictwa okrętowego. Budowa magazynow i stalych terminali przeladunowych jest także często akceptowana przez Komisje, jezcli stanowi „ponoc w celu wspierania rozwoju gospodarezego regionow, w których poziom życia jest nienormaln ie niski lub regionów szczególnie dotkniętych bezrobocien" (art. 87.2 (a)). Pomoc państwowa moze być takze udzielana w zakresic szkolenia specjalistycznego marynarzy i oficerów związanych z podnoszeniem kwalifikacji marynazu lub odnowieniem certylikatów. Ostan i rotzaj subwencji jest przyznawany w przypadku tzw. ,obowiazku sluzby publicznoj", tj. gdy panstwo zobowiązuje przewónnika do zapewnienia transportu na trasach o malym ruchu i nic przynoszacych zysku, jednakze waznych \% punktu widzenia ogólnego interesu gospodarczego (np. transport do regionów potozonych na peryferach), gdyby nomalna eksploatacja tej tasy na zasadach gospodarki rynkowej nie zapewnilaby ustug na wymaganym poziomie ${ }^{25}$.

Odięne zasady obowiazuja w budownictwie okrętowym. P’zenyst stoczniowy jest odrębną gatęzia od zeglugi morskiej, wymaga więc wielokrotnie innych rodzajów ponocy, istnieja jednakze tendencje do kączonia tych zagadnien. Dolïnansowanie kazdego z tych sektorów słuzy ogólnemu rozwoju gospodarki transportowej. Poprzez zastosowanie odpowiednich srodków mozna przekonać armatorów mających siedzibę w danym kraju do budowy statków w tym samym kraju, wspierając w ten sposób oba sektory i gospodarkę jako calość.

Przemyst sloczniowy wykazuje rówilez tendencje spadkowe: spadek zatrudnienia w UE wynosi z okolo 250 tys. osób w latach siedemdziesiatych do okoto 60 tys. osób obecnie, a spadek udzialu budownictwa okręlowego w globalnym przenyśle światowym z 35 do $20 \%{ }^{26}$. W celu waparcia upadającego sektora gospodarki uchwalono regulacje precyzujace warunki przyznawania pomocy publicznej. Pierwsza dyreklywa dolyczaca pomocy

25 J. Kujawa, op.cil., s. 115.

26 1. Me(jowan, Transport morski u progu XXI wiekt. Liberalizacja ustug aransportowyeh w ramach Jednolitego Rynku, Intcgracja J:uropejska/ L.ektuy, tód\% 1998, nr 51, s. 109 
dia przenystu stoczniowego zostata uchwalona w $1969 \mathrm{r}^{27}$ Byta ona kilkakrotnie nowolizowana ${ }^{28}$. Stosunkowo dhugo, gdyz az 7 lat obowiazywala tzw. Siódma dyrektywa o pomocy dla przemystu stoczniowego. Weszta onal w zycie 1 stycznia $1991 \mathrm{r}^{29}$ i obowiazywata do $1998 \mathrm{r}$. Obecnic obowiązuja zasady wprowadzone rozporzązenicm $1540 / 98$ Rady z $1998 \mathrm{r}^{30} \mathrm{Na}$ jego podstawie pomoc panstwowa może być udziciona wedlug zasad okréślonych proez rozpor\%ądzenie, nie może jednak powodować zakłóceń konkurencji pomiędzy stoczniami w innych panstwach czlonkowskich, ani dyskryminować towarów lub usiug ze względu na kaj pochodzenia. Wyróznia sie irzy rodzaje ponocy panstwowej udzielanej stoczniom lub armatorom: pomoc operacyjna, pomoc w celu restrukturyzacji lub zamknięcia stoczni oraz inne środki.

Pomoc typu operacyjnego moze być udzjelana dla potrzeb budowy lub przebudowy staków w celu poprawy konkurencyjności przemystu stoczniowego. Wysokośc takiej pomocy uic moźc przekraczac określonego procentu sumy, na jaka opiewa umowa o zoudowanie statku (jezeli kontrakt jest wyżsy niz 10 milionów euro - - 9\%, jezeli nizszy 4,5\% ${ }^{31}$ ). Pulap ton dotyczy wszystkich staków zbudowanyeh w ciagu trzech lat od zawarcia unowy, choć Komisja moze przedluzyć ten okres ze względu na nieprzewidziane okoliczności zaistniale podczas budowy lub skomplikowana strone techniczną zadania. W nomalnych przypadkach jodnak, gdy statek zostal ukonczony później uiz w ciągu trzech lat od zawarcia umowy, pomoc jest ograniczona putapen obowiazującym tuzy lata prod ukończeniem stalku (art. 3). Jereli wie kolejne akty prawne wnos za zany dotyckace maksy-

27 OJ 1969, I. 206, s. 25.

2s Dyrcklywa Rady 87/167/1:1:C, 261987 o pomocy dla promysiu sockniowego. O. 1987, I, 69/55; Dyrektywa Rady 90/684/LEC, 21 XII 1990 o pemocy dla promyslu stoczniowego, OJ 1990, L, 380/27; Dyrekcywa Rady 92/68/LEC: zmicniajaca Dyecklywe 90/684/L:LC, (0) 1992, C 10/3; Dyrekiywa Rady 93/115/1:C, 16 XII 1993 \%micniajacal Dyrektywe 90/684/1:1:C, of 1993. L. 326/62; Dyrektywa Rady 94/73/1:C, 19 X11 1994 zmicnia-

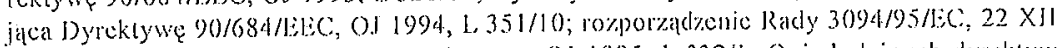
1995 o pomocy dla promyslu stoczniowego, $0.11995,1,332 / 1$. Opis kolejnych dyrektyw w: V. Power, op cil., s, 484 i 1 .

29 Siódma Dyrcklywa Rady $90 / 684 / 13 \mathrm{LC}, 21$ XIf 1900, o pomocy dia promyslu-stoc\%niowego, O. 1990, 1.,380/27.

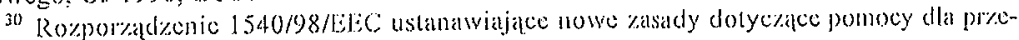
myslu stoczniowego, of $1998,1,202 / 1$.

31 Pulapy te byly wiclokrotnic zmieniane w kolejnych dyreklywach. Proykladowo Dyrck-

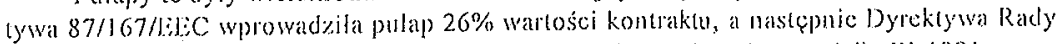
90/684/ELC obnizyla pulap do $20 \%$ i $14 \%$ (dla umów o nizsej wartosici). W $1991 \mathrm{l}$. mastapito kolejne zredukowanic pulapow do $13 \%$ i $9 \%$. Dyrcklywa Rady $92 / 68 /$ L: 1 iC wprowadzila pulapy o wysokosici $9 \%$ i 4,5\%. Obecnie Komisja precedstavila propozycje podwy\%szenia pulapu do $14 \%$ dla sloc\%ni, ktore poniosly straty w wyniku nicuczcivej konkurencji stoc\%ni poludoiowokorcanskich dotowanych przez panstwo. 
malnej wysokości pomocy, elekty tej zmiany będą musialy zostać uwzględnione przez stocznie budujące statek przez dhuzej niž trzy lata ${ }^{32}$.

Drugi rodzaj pomocy udzielany jest w przypadku zamkniegcia lub restrukturyzacji stoczni. W celu zamknięcia stoczni pomoc może zostać udzielona na pokrycie związanych z tym kosztów (np. poniesionych w wyniku zwolnienia pracowników: odprawy, wcześniejsze świadezenia emerytahe, ustugi doradcze w celu pomocy pracownikom znalezienia nowych miejsc pracy, kursy przekwalifikowujące elc. lub kosztów związanych z wykorzystaniem budynków, instalacji i infrastruktury stoczni na inne cele), pod warunkiem, ze zamknięcie stoczni jest definitywne i nieodwracalne (musi pozostać zamknięta przez co najmniej 10 lat - - art. 4.) . W $^{3.3}$ celu restrukturyzacji stoczni moźna udzielić pomocy $w$ postaci subsydiów, preferencyjnych kredytów, gwarancji kredytowych, wykupienia dhugów etc. Taka pomoc jest dopuszczalna w sytuacjach wyjątkowych, jezeli jednocześnie jest zgodna z wytycznymi Komisji dotyczacymi pomocy panstwowej ná cel ratowania lub restrukturyzacji przedsiębiorsiw w trudnościach (art. 5 rozp. \%. $1998 \mathrm{r}$.) ${ }^{34}$.

Inne środki obejmuja pomoc inwestycyjna na cele innowacyjne, dotycząca zaslosowania nowych produktów i metod w przemyśle stoczniowym

32 Decyza Komisji 98/157/EC, 5 X1 1997 dotyezaca pomocy zaolerowanej pme\% His\%paniç stoczni Astilleros Zamacona SA w związu z buclowa piçciu holownikow. OJ 1998 , 1. 50/38: his\%panska stocznia Astilleros, któn zawarla w 1990 r. kontraki na budowę 5 holownikow. W momencic zawarcia umowy pulap pomocy pastswowej wynosil $9 \%$ warLości kontraktu, ale w 1992 i. zmieniono ton pulap Dyrektywa Rady 92/68/liEC, OJ 1992, C 10/3 na 4,5\% dla kontraktow o nizstej watości. Tymczasem wejście umón w zycic zostak prosumiçe na pónicjszy okres i w rezulacie statki zostaly ukonc\%one w okresic pomiçdy lipeem $1995 \mathrm{~s}$ a majem 1996 r., w ka\%dym proypadku po troch latach od zawarcia umowy. Whad\%e hiszpanskie zwrócily się do Komisji z prośba o prodluzenie okresu

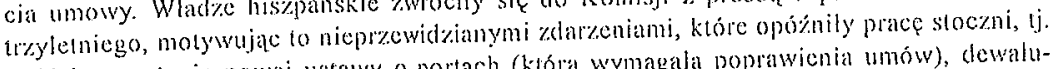
wejścicm w źchic nowej ustawy o portach (ktora wymagala poprawicnia umów), dewaluacja pesety w 1992 r. (co spowodowalo zmianç technicznej częśsi unowy dla uniknięcia rakupu drogich c\%ssci za granica, pracami reparacyinymi na tercuic pobliskicgo portu

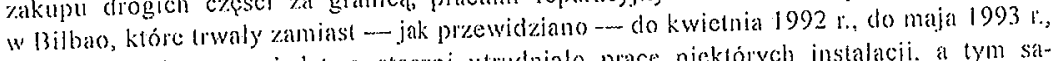
co \%c wrględu na sasiedztwo stoczni utrudinialo pracę nicktórych instalacji, a tym sámym \%redukowalo produklywnośc zakladu) oraz przejecicm prze\% Astillerosi stoc\%ni $A$ duag, na skulek nacisku his\%panskicgo Ministerstwa Przemyslu jako cześś programu restrukluyzacji promyshu stoczniowego. Komișja jednak odmoucila prośbę uznajac, $7 \mathrm{c}$ przyloc\%onc zdarenia albo nic byly niemozliwe do prewidzenia dla stoczni, albo nic molywowaly a\% tak dtugicgo opóźnienia w wykonaniu umowy. W rezulacic wysokośc udziclonej ponocy panstwowej zostala zredukowana $79 \%$ syartości kazdej umowy $40 \quad 4,5 \%$. Astilleros zaska\%yl decyzjc Komisji do Trybunalu Picrwszej Instancji, ten jednak podtrymal decyðję Komisji.

33 O. $2001, \mathrm{C} 117$.

3.) OJ 1994, C 368/12. 
(art. 6) ${ }^{35}$, regionalna pomoc inwestycyjna, która ma na celu poprawe produkcyjności istniejacych stoczni, zgodna z wytycznymi Komisji dotycracymi narodowej pomocy regionalnej ${ }^{36}$ (art. 7), pomoc dla projektów badawcymi pomocy pástwowej na rzecz prac badawczo-rozwojowych (art. 8)

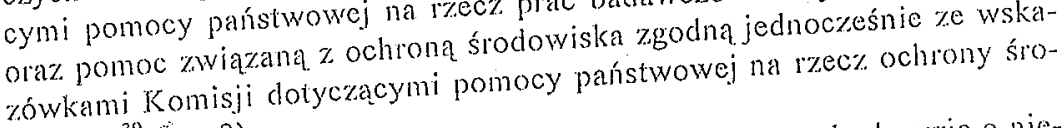
dowiska ${ }^{39}$ (art. 9).

W latach 1987-1997 Komisja wielokrotnie podejmowała decyzje o niezgodności planowanej pomocy ze wspólnym rynkiem i zabraniała jej udziclenia. Obecnie wydaje się, że ta surowa polityka nieco zelzała, ze wrględu na rosnąca konkurencję produktów ze stoczni pozacuropejskich i prypadki silnego dofinansowywania ich przez państwo (np. Pode Komisji na taka Stoczniom wspólnotowym tatwiej jest raz unyské moze być m.in. przekropomoc. Powodem niewyrazenia zreznaczenie pomocy na utrzymanie doczenie górnej granicy podsebiorstwa (tzn. odwlekanie restrukturyzacji lub nawel zwiekszenie produktywności, gdy plan restrukturyzacyjny zakładá jej zredukowanie ${ }^{40}$ ), zmiana warunków pomocowych w trakcie negocjacji

3. W oc\%ekiwaniu na decyzje Komisji pozostaje propozycja pomocy inveslycyjncj dla stoczni Schleswig-Holstein w Niemczech, Of 2001, C 23

${ }^{36}$ of $1998, \mathrm{C} 74$.

3ิ W 2000 r. Komisja zatwierdzila pomoc proyzana przemyslowi stoc\%niowemu na projekty badawc\%o-ro\%wojowe majace na celu badania nad nowa technika nawigncyjna i ulepszeniani lechnologicznymi konstrukcji stalków, Of 2001, C 37

${ }^{38}$ O. $1998, \mathrm{C} 45 / 5$.

39 of $1994, C 72 / 3$.

40 Zwot pomocy panstwowej nastapil w proypadku niemicckicj stoczni Kvacmer Warnow Werft Gmbri, Rostock-Warnemünde, która musiala zwrócić ponad 90 milionów DM Sytuacja ekonomiczna $w$ nowych landach niemicek prypadku przemyslu stoczanionely srodków z zakresu pomocy publicznej, tak więc w p w poprzez wprowadzenie Dyrektywa podwyzszono maksymalne dopuszczalne pulapy pom do Dyrektywy $90 / 684 / 1815 \mathrm{C}$ o pomocy Rady 92/68/EEC (O) 10wego do $36 \%$ rocznych obrotow sloczni. Pomoc nic mogla być jectdla przemyslu stoczniowego podukcyjnc, a miala dażyć do nieodwracalnic redukcji mocy nakze przyznawana na cele proc a produkcyjnych. Stocznia KW. Warmakiem otrzy'mania pomocy było przeprowadzenic pryez. mknięcie nicktós redukcji produktywności przemyslu stoczniowego o $40 \%$ do końca roku 1995 oraz. ograniczenic produktywności stoczni KWW do 85000 ton gross rocznic. Mimo to stocznia przekroczyła ustanowiony próg w latach 1997, 1998 i 999. Komisja uznala pomoc udzie-

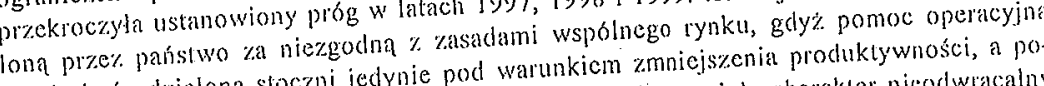
mogła być udzielona sloczni jedynie pod warunkion acic to mialo charakter nieodwracalny moc na cel zanknięcia doków jedynie jeżeli zócic cz̨̧śc pomocy państwowej zal lata, w któ(art 6, 7 Dyr. 90/684). Stocznia musing Zecyzja Komisji 1999/675/1:C, 8 VII 1999 o po- 
związanych z budową statku, niedozwolony sposób wsparcia restrukturyzacji stoczni (np. przejęcie pakietu holdingowego przoz stocznie w firmie spoza sektora poniżej wartości rynkowej), etc.

Zasady dotyczące pomocy publicznej w Polsce są zamieszczone w ustawie o warunkach dopuszczalności i nadzorowaniu pomocy publicznej dla przedsiçbiorców z 30 ezerwea 2000 r. Ustawa ta ma na celu, zgodinie z wymogani Układu Europejskiego, hamonizacje zasad dotyczacych ponocy publicznej w Polsce z prawen europejskim. Przepisy w niej zawarte stosuje się do pomocy, której tączna wartość w ciągu kolejnych trzech lat przekracza kwote 100 tys. euro oraz do pomocy sektorowej i eksportowej niezaleznie od jej wielkości (art. 2). Pomoca publiczna jest ,przysporzenie, bezposreónio lub pośrednio, przez organy udzielajace ponocy, korzyści finansowych okreśtonym przedsiębiorstwom, w następstwie którego uprywilcjowuje sie ich w stosunku do konkurentów, przede wszystkin w drodze dokonywania na rzecz lub za tych przedsiębiorców wydatków ze środków publicznych lub pomniejszania świadezeń należnych od nich na rzecz sektora finansów publicznych na podstawie odrebuych ustaw lub innego tytulu prawnego" (art. 4.1). Jako formy pomocy publicznej ustawa wymienia dotacje bezpośrednie, ulgi podatkowe, dokapitalizowanie przedsiebiorców na warunkach odbiegających of nomalnych praktyk inwestycyjnych, pozyczki i kredyly udzielane na warunkach korzystniejszych niż rynkowe, poręczenia i gwarancje udziclane za zobowiazania przedsiębiorstw na warunkach kozystniejszych niz rynkowe, zaniechanje lub odroczenje zobowiązania podakkowego, umorzenie, odroczenie lub rozkozenie na raly innych świadczeń publicznych naleznych Skarbowi Państwa oraz zbycie lub oddanie do korzystania mionia Skarbu Państwa lub jednostek samorządu terytorialnego na warunkach korzystniejszych niz rynkowe (art. 4.1). Ustawa wyróznia uzy rodzaje pomocy: regionalna sektorowa i horyzontalna. Pomoca regionalua jest pomoc, klórej warunkiem udzielenia jest prowadzenie dzialalności gospodarczej w ok!cślonym regionie (art. 4.4), sektorowa -- pomoc, której warunkjem udzielenia jest prowadzenie przez przedsiębiorce ok eślonej przedmiotowo działalności gospodarczej (art. 4.5), a pomoca horyzontalna laka pomoc, której warunki udziclenia nie są związane ani z prowadzeniem dziatalności nal określonym obszarze, ani w określonym scktorze (art. 4.6). W ranach warunków dopuszczahności pomocy ustawa powotuje sie ná umowy niçdzynarodowe, a w szczególności na laczacy Polskę i Wspólnoty

mocy palistwowcj adziclonej pr\%. Nicmey na rece stuezni Kvacrner Warnow Werl Gimblt, of 1999, L. 274/23; Decyzja Komisji 2000/336/1, C, 15 Il 2000, OJ 2000, L, 120/12; Decyrja Komisji 2000/416/8C, 29 l11 2000, OJ 2000, L. 156/39. Por. Lakie L. Pawlowski, pomoc publiczna wekcorze stoczniowym w UE, lw: l Pomoc publiczna dla pradsigbiorstw w. Unii Europejskiej $i$ w Polsce, Warszawa 1998, s. 103-10.5. 
Uklad Europejski (art. 5). Szczególowe zasady przewidziane przez ustawe są zgodne z zasadani zawartymi w traktacie rzymskim. Wedlug ustawy dopuszczalna jest pomoc:

1) udziclana w celu naprawienia szkód wyrządzonych przcz klęski żywiolowe lub inne nadzwyczajne zdarzenia,

2) o charakterze socjalnym dla indywidualnych konsumentów, pod warunkiem. żo jest ona przyznana bez dyskryminacji zo względu na pochodzenie towarów (art. 6.1).

Ponadto, za dopuszczalna można również uznać pomoc, która zostaka udzielona w celu:

1) likwidacji poważnych zaklóceń w gospodarce o charakterze ponadsektorowym,

2) wsparcia krajowych przedseębiorców działających $w$ ramach przcdsięwzieccia gospodarczego podejmowanego w interesje europejskim,

3) promowania kultury, nauki i oświaty oraz ochrony dziedzictwa kulturowego (art. 6.2).

Pomoc nie moze jedynie finansować bicżacej drialahości przedsiçbiorstwa. Musi być udzielona w celu wsparcia nowych inwestycji lub (worzenia nowych micjse pracy zwiazanyeh z takimi inwestycjami (art. 8.1). Dopuszczalna jest równiez pomoc nie zwiąana z nowymi inwestycjami, jeżeli jest doraźna, restrukturyzacyjna, dla malych i średnich przedsiębiorstw w formie poręczen splaty kredytów lub w celach wymienionych powyzej (naprawa skutków klęski żywiołowej, ponoc o charakterze socjalnym, w celu ochrony dóbr kultury etc. - art. 8.4). Udzielone wsparcie musi być degresywne, ij. stopniowo zmmicjszające siç i ograniczone w czasie (art. 8.5). Warunki te zgadzaja sic z zasadami pomocy publiczncj w prawie europejskim. Ustawa polska idzic nawet dalej, przewidujac ustawowo dodatkowe warunki dopuszczalności pomocy (art. 9). Oprócz spelnienia warunków wymienionych powyzej, pomoc publiczna musi równiez stanowić uzupelnienic innych środków niż publiczne w przypadku inwcstycji lub tworzenia nowych micjsc pracy. Państwo nie mołe finansować całej inwestycji, część jej kosztów musi pokryć sam przedsiębiorca. Wielkość pomocy, czas trwania i zakres muszą być proporcjonalne do celu, jaki ma osiągnać. Dotowane projekly wspierane są tylko w zakresie, w jakim jest to niezbędne i tylko przez taki okres, w jakim jest to konjecznc. Ponoc musi równocześnie przynieść korzyści spoleczne, większe niz koryści moziliwe do osiagnięcia bez jej udzielenia. Pomoc publiczna musi być przejrzysta.

Niedopuszczalna jest pomoc, któla ogranicza lub znicksztatca konkurencję lub uniemozliwia powstanie konkurencji. Wyjątek wprowadzony jest jedynie dla ograniczonej w czasie pomocy regionalnej dla regionów ubogich oraz restukturyzacji przedsjębiorstw. 
Dalsze przepisy uslawy precyzują szczególowo zasady dopuszczalności pomocy regionalnej, horyzontalnej i sektorowej. Wedtug art. 12 dopuszczalna jest pomoc dla regionów szczególnie ubogich, tj. charakteryzujacych się poziomem produktu krajowego brutto na jednego mieszkańca ponizej $75 \%$ średniego poziomu krajowego we Wspólnotach Europejskich (pomoc regionalna). Pomoc horyzontalna obejmuje szereg programów, których zasady uwzględniaja zasady dotyczące odpowiadających programów we Wspólnotach Europejskich, m.in. restrukturyzacje przedsiebiorstw, prace badawczo-rozwojowe, utrzymanie poziomu zatrudnienia lub tworzenia nowych miejsc pracy, rozwój małych i średnich przedsiębiorstw, ochronę srodowiska, inwestycje energooszczędne, rozwój infrastruktury technicznej, rehabilitacje i zatrudnianie osób niepelnosprawnych, szkoleniá pracowników zwiąane z rozwojem przedsiębiorstwa (art. 16.1).

Poniewaz niniejsze rozwazania koncentruja się na zagadnieniu wspicrania przenystu stoczniowego i zeglngi morskiej, \% tego wzgledu najbardziej interesujaca jest pomoc sektorowa. Taka pomoc jest dopuszacalna, jezeli „przyspiesza niezbędne zmiany lub rozwój określonych sektorów, przywraca dugotrwate funkcjonowanie określonych sektorów lub lagodzi spoleczne i gospodalcze koszly zmian w określonych sektomch w oznaczonym okresie" (art. 14.1). Na podstawie art. 14.2 ustawy o pomocy publicznej Rada Ministrów, w drodze rozporzadzenia, określa sektory, w których moze być stosowana pomoc sektorowa, szczególowe warunki jej dopus\%czalności, maksymalne pulapy i obowiazki zwiazane z monitorowaniem. Uwzględnienia wymaga równiez konieczność restrukturyzacji danego sektora, nadwyzka mocy produkcyjnych oaz spadek popytu. Natomiast wedtug art. 37.3 ustawy Rada Ministrów określi, równiez w drodze rozporzązenia, „przedsiebiorców zobowiazanych do sktadania organowi nadzolujacemu sprawozdań dotyczacych otrzymanej pomocy, zakres obowiazków sprawozdawczych, okresy sprawozdawcze, termin skladania sprawozdań, wzól formularza" i zakres wymaganych informacji pozwalających ocenić skuteczność $i$ efektywność pomocy oraz jej wplyw na konkurencję. Na podstawie tych dwóch artykutów, Rada Ministrów wydala 20 lutego 2001 r. rozporzadzenie w sprawie udzielania pomocy publicznej w scktorze zeglugi morskiej.

Nadzorowaniem pomocy publicznej zajmuje się Plezes Urzędu Ochrony Konkurencji i Konsumentów. Ma on za zadanie m.in. monitorowanie i nadzorowanie udziclanej pomocy poprzez kontrole jej zgodności z ustawą o pomocy publicznej i umowami międzynarodowymi (a więc w szczególności Uktadem europejskim), ocenę skuteczności i efektywności pomocy, wymiane informacji na zasadzie waajemności na podstawie zobowinzan międzynarodowych (a więc przedstawianie informacji o ponocy publicznej w Polsce Komisji Europejskiej) i wreszcie przedstawianie sprawozdań Ra- 
dzie Ministrów (art. 23). Ponadto, opiniuje on projekty aktów normatywnych stanowiacych podstawe udzielenia pomocy, przedkladane przez organy administracji rządowej i samorzadowej (opinia musi być wydana w ciągu $30 \mathrm{dni}$ - art. 24).

Ustawa określa również procedure przyznawania pomocy. Organ, któly zamierza takiego wsparcia udzielić, przedstawi Prezesowi Urzędu projekt. Prezes opiniuje plan pod względem jego zgodności z zasadami Konstytucji, omawianej ustawy i umów międzynarodowych i wydaje w ciągu 60 dni opinię (jeżeli pomoc ma postać poręczenia lub gwarancji - $-w$ ciągu 30 dni) (art. 25). Informacja o przedrożonym projekcie zostaje równiez zamieszczona przez Prezesa Urzędu w Monitorze Sadowym i Gospodarczym (art. 27). Jezeli pomoc jest zgodna z prawem, zostanie dopuszczona. Prezes Urzędu moze jednakze postawić warunki, jakie organ udzielający pomocy musi spetnić, aby była ona godna $z$ prawem (art. 26.1). Jezeli natomiast uzna on, ze planowana pomoc nie jest zgodna z prawem, wyda odpowiednia decyzje i zabroni jej udzielenia. Opinia Prezesa Urzędu jest równiez ogłaszana w Monitorze (art. 30.1). Dalsze przepisy proceduralne ustawy reguluja kwestie uznania przez organ nadzorujący, ze ustawa będaca podstawa udzielenia pomocy jest niezgodna z ratyfikowanymi umowami miçdzynarodowymi lub Konstytucja i skierowania problemu do rozpatrzenia przez. Trybunat Konstytucyjny oraz zwrotu otrzymanej pomocy (art. 31), a tak\%e stwierdzenia przez. organ udzielajacy pomocy, ze pomoc ta jest wykor\%ystywana niezgodnie z przeznaczeniem i nakazaniu jej zwrotu (art. 33). $W$ obu przypadkach wymaga sic zwrotu otrzymanej pomocy wraz \% odsetkami, ściagniecie której - jeżeli zwrota nie dokonano dobrowolnie -.. przeprowadzane jest wedtug przepisów o postępowaniu egzekucyjnym w administracji (art. 33.2).

Ostatni problem rozstrzygany przez ustawe dotyczy monitorowania pomocy i przejrzystości informacji. Organy udzielające pomocy są zobowiazane do badania jej skuteczności i efektywności oraz do przedkladania Prezesowi Urzędu oraz ministrom finansów i gospodarki sprawozdań kwartalnych dotyczacych udzielonej pomocy (art. 35). Urząd Ochrony Konkurencji i Konsumentów prowadzi na podstawie otrzymanej informacji rejestr udzielanej $w$ Polsce pomocy i prowadzi w tej kwestii wraz $\%$ ministrem finansów roczną sprawozdawezość dla Rady Ministrów (art. 36, 39). Rada Ministrów przedstawia podobne sprawozdanie Sejmowi do końca kazdego roku kalendarzowego (art. 40).

Sektory, gdzie taka pomoc jest dopuszczalna, warunki dopuszczalności pomocy, maksymalne pulapy, sposób i obowiazki zwiazane z monitorowaniem określi Rada Ministrów w drodze rozporządzenia (art. 14.2). W przypadku zeglugi morskiej takie rozporzadzenie zostało wydane 20 lutego $2001 \mathrm{r}$. Za przedsiębiorców kwalifikujących się do otrzymania pomocy 
uwaza się, wedfug $\$ 2$ rozporządzenia oraz rozporzadzenia Rady Ministrów w sprawie Polskiej Klasyfikacji Dzialalności (PKD) ${ }^{41}$, przedsiębiorców świadczacych usługi norskiego i przybrzeznego transportu morskiego ${ }^{\text {i2 }}$ i ushugi pomocnicze oraz stocznie produkcyjne i remontowe w zakesie, $w$ jakim prowadza wyżej wymienioną dzialalność. Wedtug kodeksu morskiego ,ushlugami w żegludze" sa uslugi agencyjne, maklerskie, holownicze i pilotazowe (3. $^{4}$ Ze względu na ich charakter szanse na otrzymanie pomocy będa mialy najprawdopodobniej przedsiębiorstwa zajunjące się holowaniem portow'yn i dalekomorskim lub pilotowanien statków. Eksploalacja statku wymaga równicz innych usług, np. przeladunkowych, sztauerskich, trymerskich, remontowych $i$, mimo ze hie są one nazwane w kodeksie morskim, wydaje sie, zo ze wærględu na ich chamakter pomocnic\%y dla zeglugi, przedsiębiorstwa je świadczące będa mogly równiez ubiegać się o wsparcie. Równiè stocenie produkcyjue i remontowe bẹda kwalifikowaly się do otrymania pomocy dla wsparcia swojej dziatalności, o ile świadcza usługi w zakresie tansportu, holowania, pilotowania, remontów statków lub inne uslugi pomocuic\%e.

Rozporządzenie $z 2001$ r. określa równiéz rodzaje pomocy dopuszczalnej dla przedsiębiorstw żeglugowych: pomoc na restrukturyzację, utrymanie poziomu zatrudnienia, inwestycyjna. (w tym na poprawę bezpieczeństwa morskicgo), na szkolenia specjalistyczne, ochronę środowiska morskiego, inwestycje energooszezędne oraz wspicranie prac badawczo-rozwojowych (乌̧ 3 rozporzadzenia).

Ponoc restrukturyzacyjua udzielana jest przedsiębiorstwom, które tracą zdolność do konkurowania na rynku, odczuwaja negatywne skutki spadku popytu i nadmierncj zdolności produkcyjnej, co w konsekwencji powoduje wzrost zapasów, spadek zyskowności, ponoşzenie strat, wzrost zadiluzenia i brak możliwości uzyskania bankowych kredytów. Udzielone im wsparcie ma na celu przywrócenic przedsiębiorstwu dlugookresowej zclolności dó konkurowania na rynku. Jest oparte na planie restrukturyzacji i niejednokrotnie powiazane $z$ prywatyzacją przedsiçbiorstwath. Pomoc ta ma wielokrotnie na celu zmniejszenie zdolności produkcyjnych danego przedsię-

11 b\%U. \% 1997 r. Nr 128, poz. 829.

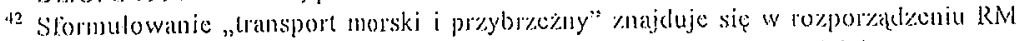
w spravic Polskicj Klasyfikaçi Dzialahości, choć talinicjszy bylby podzial ha transport dalckomorski, morski i przybrzckny.

${ }^{13}$ J. Lopuski w: Prawo morskie, t. II (2), Byclgos\%c\%-worun 2000, s. 17.

* W taki sposób dokonano prywatyzacji wiclu panstwowych linii lounicæych. Ponoc panstwowa zostala im udziclona jedynie pol takin warunkicm. Por. J. Batfour, the BC Commission 's Policy on State Aids for Airline Restructuring: Is the Bonfire Alight?, Air and Space Law 1995, v. XX, s. 60 i n.; J. Ballowr, The control of state aids in the air tratspon sector: Nir and Space l.aw 1993, v. XVIII 1993, p. 199-204. 
biorstwa, szczególnie gdy cały sektor charakteryzuje się ich nadmicmościa. Taka syluacja istnieje niewalpliwie w przemyśle sloczniowym na skutek konkurencji z krajów azjatyckich. Pomoc nie może znieksztalcić konkurencji na danym rynku, musi być proporcjonalna do poniesionych kosztów spolecznych $\mathrm{i}$ innych oraz do zamierzonego celu (\$ 4 rozporzadzenia wraz $z$ art. 17 ustawy o pomocy publicznej).

Pomoc na utrymanie poziomu zatrudnienia jest udzielana na czas określony i ma charakter doraźny lub restrukturyzacyjny. Jest ograniczona do obszarów o pozionie produktu krajowego brutto na jednego micszkańca niższym niż. 75\% śrechniego poziomu we Wspólnolach Europejskich w ciagu ostatnich trzech lat. Ponoc może być związana ze szkoleniami lub pr"zekwalifikowaniem pracowników (\$ 5 rozporządzenia wraz z alt. 19.1, 3 ustawy o pomocy publicznej). Ze względu na nadprodukcje w tym sektor\%e pomoc nie proysluguje na tworzenie nowych miejse w pracy.

Pomoc inwestycyjna możc być przeznaczona na zakup nowych lub używanych statków przez przedsiębiorców świadezących ushugi transportu morskiego i ustugi pomocnicze lub na przebudowę, odbudowanje albo modemizację statków do nich należacych, w celu dostosowania ich do zmienionych potrzeb przewozowych lub wymogów konwencji miçdzynarodowych (\$ 6. i rozporzadzenia). Udziclona pomoc nie moze przekraczac $10 \%$ wartości inwestycji przy zakupie statków lub $25 \%$ wartości inwestycji przy ich przebudowie i modernizacji (\$ 6.2 rozporzadzenia). Jezeli pomoc inwestycyjna zostata udziclona w celu poprawy berpieczeństwa morskicgo, moze ona zostać przeznaczona wylącznie na zakup i wyposazenie statków w urządzenia i aparaturę niezbędną dla clostosowan a statków do wymogów bezpieczeństwa wynikajacych z miçdzynarodowych konwencji, m.in. IMO i ILO. Putap tego rodzaju pomocy nie moze przekroczyc 50\% kosztów (§ 6.3, 4 rozporzadizenia).

Ponoc przeznaczona na szkolenia specjalistyczne dotyczy szkolen zwiazanych be zpośrednio z rozwojem przedsiębiorstwa. Moga być one lak teoretyczne, jak i praktyczne, dotyczace obecnego lub przyszlego stanowiska pracy danego pracownika. Muszą być ściśle związane ze specyfiką dziatań przedsiçbiorstwa tak, aby zdobyte kwalifikacje nie mogly zostać wykorzystane przez pracownika u szerokiego grona innych pracodawców. W przypadku transportu morskiego, pomocy można udziclać jedynie na podnoszenic kwalifikacji zawodowych czlonków zatóg plywajacych na stakkach morskich. Pulap pomocy nie moze przekroczyć $25 \%$ kosztów szkolenia. W przypadku malych i średnich przedsiębiorstw putap ten ulega podwyzszeniu o kolejne 10\% (\$ 7 rozporzadzenia wraz z arl. 22 ustawy o pomocy publicznej).

Pomoc na ochronę środowiska morskiego lub inwestycje energooszczędne w zakresie dostosowywania urządzeń do nowych wymagań praw- 
nych ochrony środowiska może wynosić $15 \%$ inwestycji oraz $25 \%$ w przy padku malych i srednich przedsiębiorstw, natomiast pomoc na inwestycj dowiska aź do poniźej wymagań prawnych może wynosić odpowiednio $30 \%$ oraz $40 \%$ inwestycji dla malych i średnich przedsiębiorstw (\$ 8 rozpo rzadzenia wraz z art. 20 ustawy o pomocy publicznej).

Wspieranie prac badawezo-rozwojowych ma na celu udzielanie pomo rymentalna i teoretyczna podejmowana w celu zdobycia nowej wiedzy o z.jawiskach i faktach, nie ukierunkowaną na bezpośrednie zastosowanie w praktyce", „badania przemystowe - planowe badania mające na celit pozyskanie nowej wiedzy, która może być bezpośrednio przydatna do oprá. cowywania nowych albo znaczacego udoskonalenia istnicjących produk tów, procesów lub usfug" oraz "badania przedkonkurencyjne obejmujace projekty nowych, zmodyfikowanych lub udoskonalonych produktów, wta-

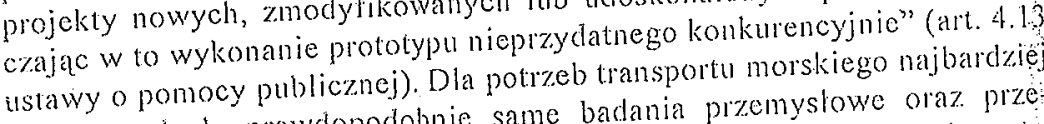
przydatne becda prawdopodobnie same badania przemyslowe oraz przeksztalcanie ich wyników. Organy udzielajace pomocy na cele badawczo-rozwojowe powinny uwzgledniać prograny ustanowione w tym zakresié prez. Wspólnoty Europejskie, wspierać badania o róznych kierunkach dostępność do w ten sposób uzyskanych wyników badań (\$9 rozporądzenia wra\% zart. 18 ustawy o pomocy publicznej).

Rodzaje dopuszczanej pomocy sa zgodne \% odpowiednimi rodzajami pomocy dla przedsiębiorstw żglugowych dopuszczonymi na podstawie weześniej omówionych wytyeznych Komisji. Róznną się jednakze przewidziane putapy. W polskim rozpolzadzeniu są one wyrazone najeześciej procentowo w stosunku do kosztów danej inwestycji, natomiast wedlug. wytycznych dopuszczalnym putapem pomocy dla żeghugi jest catkowita redukcja podatków i świadczeń socjalnych marynarzy, a także podatku dochodowego z dzialalności żeglugowej (alternalymnie wysokość bezpośrednich subwencji nie moze przekroczyć wysokości tych ulg). Trudno porównać oba pulapy. Wydaje się, że putap wspólnotowy jest w praklyce wyższy, gdyz danemu przedsiębiorstwa można w reeczywistości pozostawić calość wypracowanych przę niego srodków. Wedtug prawa polskiego środki publiczne finansują jedynie do $50 \%$ inwestycji, co prawdopodobnie nigdy nie osiagnic wysokości limitu przewidzianego w prawie europejskim.

Rozporządzenie prewiduje również obowiązi związane z monitorowaniem pomocy, które stanowią uzupelnienie zasad przewidzianych w ustawie o pomocy publicznej w art. 23-40. Wedtug rozporządzenia, przedsie- 
biorca świadczacy ustugi transportu morskiego lub pomocnicze, który uzyskat pomoc publiczna, zobowiazany jest do przekazywania organowi nadzorującemu (a więc Prezesowi Urzedu Ochrony Konkurencji i Konsumentów) rocznego sprawozdania ( $w$ ciagn 90 dni od zakończenia roku kalendarzowego). Powinno ono zawierać nazwe firmy, jej adres wielkości struktury dotyczace struktury whasności, liczby zatudnionych, we chodzi o udziclona przewozów oraz dane ekonomiczno-finansowe. formie, przeznaczeniu, wyjących, wykorzystanin pomocy, stopninno przedstawić sytuację przedsięzowych. Ponadto, sprawozdané jego udziału w rynkach, na których dziata biorstwa na rynku, l. womo pomocy dia konkurencji na rynkach, których dotyczy pomoc sektorowa ( $\$ 10-12$ rozporządzenia).

Pomoc publiczna dla sektora budownictwa okrętowego jest regulowana odrębnie, w rozporzązeniu RM wydanym równiez 20 lutego $2001 \mathrm{r}$. Wsparcie otrzymac moga przedsiębiorcy prowadzacy dzialaho masie nie mniejdukcji, naprawy i konserwacji statków petnomor odbudowy statków pelnomorskich o masic szej niz $100 \mathrm{gt}$ ora\% generalnej odbudow 3 rozporzadzenia). Dopuszezalna jest pomoc nie mniejszej niz $1000 \mathrm{gl}(8$ a

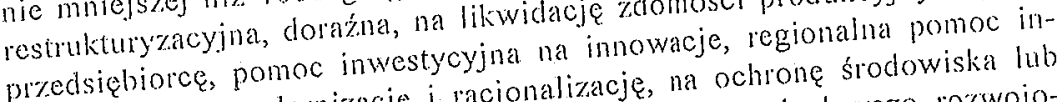
westycyjna na modernizację i racjonalizacje, na ochronę śodowiska lub inwestycje energooszczedne oraz na wspieranie prac badawczo-rozwojowych $(\$ 4)$

Pomoc restrukturyacyjna musi mieć na celu nieodwracalne zmniejszenie zdolności produkcyjnych sloczni, co oznacza niewykorystywanie

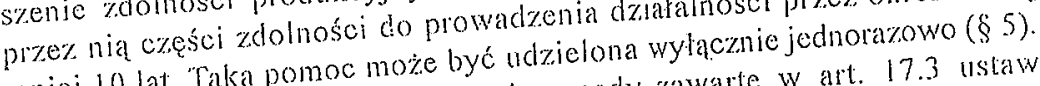

Do pomocy donánej stosujé ona przeznaczona na restrukturyzacje o pomocy publicznej. Musi bić mu odzyskanie płynnosci finansowej oraz musi być ograniczona do pożyczek, kredytów, poręczen, gwarancji, roziozenia na laty lub odroczenia terminu ptatności świadczeń stanowiących środki publiczne. Ponadto moźe mieć ona wytącznie jednorazowy charaktes i moze być świadczona jedynie przez okres nie przekraczajacy 6 miesiecy.

Pomoc na likwidacje zdolności produkcyjnych jest dopuszczalna jedynie w zakresie, w jakin pokrywa koszty oston socjalnych wyptacanych pracownikom zwalnianym lub przechodzacym na woześniejszal emerytures, ustug doradczych dla pracownikow zwolnionych, przekwalifikowania pracownikow, prabuclowy budynków oraz dostosowywania urądzén i infrastruktury technicznej do wykorystania w innej dzialalności (\$ 7.1). Wysokość 
tej pomocy nie może przekraczać zdyskontowanej wartości przewidzianych kosztów stałych przedsiębiorcy w okresie trzech lat, pomnicjszonej o korzyści uzyskane z tytulu likwidacji zdolności produkcyjnych w zakresie sektora budownictwa okrętowego oraz wartości księgowej netto likwidowanych urządzeń (\$ 7.2).

Pomoc inwestycyjna na innowacje noże dotyczyć jedynie wprowadzania na skalę przenystowa nowych wyrobów i procesów produkcyjnych (\$8.1). Wysokość tego wsparcia nie może przekraczać 10\% tącznych kosztów zwiazanych z działalnością konstrukcyjna i inwestycjami, poniesionymi bezpośrednio i wyłącznic na tïnansowanic innowacyjnej czessei projektu (\$ 8.2). Ponadio, dopuszczalna jest pomoc inwestycyjna przeznaczona na modernizacje lub racjonalizację na obszarach objetych kwalifikacją dla pomocy regionalnej wedhug art. 12 i 13 ustawy o pomocy publiczncj. Ta pomoc może jedynie mić́ na celu zwiększenie wyclajności istniejacych urządzeń (\$9). Maksymalna intensywność tej pomocy wy'nosi 22,5\% kosztów (\$9.3).

Do pomocy na ochronę srodowiska lub inwestycje energooszezedne stosuje sic art. 20 ustawy o pomocy publicznej $(\$ 10)$. Na tej podstawie pomoc dla dzialań przedsiębiorcy w zakresie ochrony śodowiska powinna być przyznawana $z$ zachowanjem pułapów przewidzianych dla regionów kwalifikujacych sie do pomocy regionalnej. W przypadku inwestycji związanyeh z dostosowywaniem urądzeń do nowych wymagań prawnych z zakresu ochrony środowiska pulap ten wynosi $25 \%$ kosztu inwestycji dla matych i średnich przedsiçbiorstw i $15 \%$ clla pozostalych, a w przy padku inwestycji w urządzenia pozwalajace na istotne obnizenie zanieczyszczenia środowiska poniżej obowiazzujących wymagań prawnych - $40 \%$ kosztu inwestycji dla małych i średnich przedsiębiorstw i 30\% dla pozostalych. Przepisy te stosuje sie odpowiednio do inwestycji energooszczędnych.

Do pomocy na wspieranie prac badawczo-rozwojowych stosuje sie art. 18 ustawy o ponocy publicznej $(\$ 11)$. Oznacza to, że organy udzielające takiej pomocy powinny uwzglęclnić progranny ustanawiane przez Wspólnoty Europejskie w tym zakresie oraz różnicowá kierunki j wielkość takicj pomocy, aby zminimalizować ryzyko nicpowodzenia. Wyniki badań uzyskanych dzięki takicj ponocy powinny być dostępne. Maksymalne wielkości ponnocy w zakresie prac badawczo-rozwojowych zostana przewidziane w odrębnym rozporządzeniu RM.

Omawiane rozporządzenie przewiduje równiè obowiązk związane z monitorowaniem pomocy. Przedsiçbiorca, klóry takic wsparcie otrzymat, zobowiązany jest do przekazywania organowi nadzorującemu rocznych sprawozdań - w teminie 90 dni od zakończenia kazdego roku kalendarzowego. Powinny one zawierać informacje dotyczące: nazwy, siedziby i adresu przedsiębiorcy, struktury wiasności przedsiębiorstwa, struklury grupy kapitało- 
wej, liczby zatrudnionych, wiclkości. i struktury produkcji, danych ekonomiczno-finansowych, form, tytulu, kwot, intensywności, podstaw prawnych ponocy i organu jcj wzielającego, wykorzystania otrzymanej pomocy, siopnia wykorzystania zdolności produkcyjnych, poszczególnych grup produktowych oraz rynków działalności i udzialu w tych rynkach (\$13).

Do niedavina w Polsce nie stosowano bezpośrednich subwencji dla żcglugi. Oprócz ulg fiskalnych, armatorzy byli jedynie zwolnieni z poclatku od sprzedazy statku pod warunkiem, ze pieniądze uzyskane ze sprzedazy zostalyby w ciagu czterech lat zainwestowane w inwestycje tonazowe. Szczególnyin problemen dla polskich przedsiębiorstw żeglugowych byl i wciąz jest wysoki odpis na świadczenia socjalne pracowników oraz wysoka stopa podatku dochodowego dla przedsigbiorstw. Pomoc publiczina udzielana przedsiębiorstwom żeglugowym pomoże zapewne niektórym z nich odzyskać konkurencyjność i przeprowadzić znaczącą restrukluryzację. Nie wiadomo jechak czy zatrzyma ona "wyflagowywanie się" statków. Mimo wzrostu pomocy publiczncj dla żeglugi w WE proces ten nie zostal zahamowany w znaczący sposób. Uprawianie żeglugi pod dogodną banderą przynosi wciaż armatorom ogromne oszczędności. Państwa europejskie nie będą mogły nigdy zaoferować tak niskich koszlów eksploatacji w szczególności ze względu na kladziony przez nic nacisk na wysokic standardy bezpieczeństwa statku.

Ponadto, w szczególnie trudnej sytuacji znajduje się przemysł budownictwa okrętowego. Uchwalone rozporządzenie dotyczące pomocy public\%. nej w tym sektorze może przynieść korzystne zmiany, gdyz stworzyto prawne podstawy dla wspicrania tego przenyslu. Bez pomocy ze strony państwa trudno wyobrazić sobie jego restrukturyzacje. Zasady zawarte w polskim rozporządzeniu zostaly oparte na zasadach prawa europcjskiego. Wprowadzono równiéz podobne maksymalne putapy pomocy. W Polsce nic dopuszcza siç jednak tzw. pomocy opcracyjnej, udzielanej we Wspólnocie na potrzeby budowy lub przebudowy statków w celu poprawy konkurencyjności przenyslu stoczniowego (pułap wynosi obecnie w WE 9\% lub 4,5\% kosztów budowy). Taka pomoc byłaby korzystna, a o jej przydatności świadczy czçste zastosowanic we Wspólnocie. 